\title{
Nesting biology of the leafcutting bee Megachile (Pseudocentron) gomphrenoides (Hymenoptera: Megachilidae) in an agro-ecosystem
}

\author{
Juan Pablo Torretta ${ }^{1,4}$, Silvana Patricia Durante ${ }^{2}$, María Guadalupe Colombo ${ }^{2}$, \\ Alicia Mabel BASILIO ${ }^{3}$ \\ ${ }^{1}$ Facultad de Agronomía, Cátedra de Botánica Agrícola, UBA. Av. San Martín 4453, Buenos Aires, Argentina \\ ${ }^{2}$ División Entomología, Museo de La Plata, Paseo del Bosque s/n, B1900DNG, La Plata, Argentina \\ ${ }^{3}$ Cunicultura y Apicultura, Facultad de Agronomía, Cátedra de Avicultura, UBA. Av. San Martín 4453, Buenos \\ Aires, Argentina \\ ${ }^{4}$ Consejo Nacional de Investigaciones Científicas y Técnicas, Buenos Aires, Argentina
}

Received 26 October 2011 - Revised 2 March 2012 - Accepted 18 March 2012

\begin{abstract}
The nesting biology of the leafcutting bee Megachile (Pseudocentron) gomphrenoides Vachal (Hymenoptera: Megachilidae) was studied in an agro-ecosystem in the Province of Buenos Aires, Argentina. Data were obtained from trap-nests placed in the field margin during two agricultural years $(2008 / 2009$ and 2009/2010). Females made an average of 7.55 cells per nest, and used leaves of at least three plant species to build their nests. Provisions of cells were principally of Asteraceae pollen. Adult emergence showed a bimodal pattern suggesting a facultative bivoltinism life cycle. Approximately, $30 \%$ of all offspring failed to complete development to the adult stage and an additional $10 \%$ were killed by natural enemies. These included parasitic wasps (Eulophidae: Melittobia and Horismenus), a cleptoparasite bee (Megachilidae: Coelioxys), and a bristle beetle (Meloidae: Tetraonyx). The host/cleptoparasite association between M. gomphrenoides and Coelioxys remissa constitutes the first such record for both species, and the Megachile-Tetraonyx interaction was previously unknown. M. gomphrenoides possesses some characteristics that make it an interesting potential opportunity to use this species for pollination of commercial sunflowers in the Pampean region.
\end{abstract}

solitary bees / trap-nest / pollination / Argentina

\section{INTRODUCTION}

Bees are essential organisms in most terrestrial natural communities because of the pollination services they provide to plants (Roig Alsina, 2008). Agricultural expansion and intensification are recognized as two of the most important global threats to biodiversity through the modification of pristine areas and the intensification of current agricultural practices (Donald and Evans,

Corresponding author: J.P. Torretta, torretta@agro.uba.ar Manuscript editor: James Nieh
2006). Throughout the Americas, these activities have been pointed out as a major threat to bees (Kremen et al., 2002; Silveira, 2004; Freitas et al., 2009). In the Pampean region, agricultural intensification threatens native animals through habitat destruction, fragmentation and/or loss of quality of original habitat, the introduction of competing animals, and direct human impact (Medan et al., 2011). For this reason, it becomes necessary to study the diversity and ecology of bees in these agro-ecosystems. We currently are examining the apifauna associated with trap-nests in agroecosystems in the Inland Pampa (Durante and Torretta, 2010; Torretta and Durante, 2011). 
Leafcutting bees are common insects and many are important and efficient pollinators of crops and other plants (Raw, 2004; Pitts-Singer and Cane, 2011). All leafcutting bees species are solitary and most nest in pre-existing cavities in the ground, wood, stems, or even arboreal termite nests. They typically cut leaves, petals, or even use chewed leaves (sometimes mixed with mud/pebbles) to line their cells and the partitions between them (Krombein, 1967; Raw, 2004; Buschini, 2006; Michener, 2007). The bee subgenus Pseudocentron Mitchell is a primarily neotropical group, being the largest South American subgenus of Megachile (Michener, 2007), with 64 recognized species (Ascher and Pickering, 2011). It is represented by 17-19 species in Argentina (Moure et al., 2007; Raw, 2007; Durante et al., 2008), but little is known about their biology and there are no taxonomic keys for their determination.

The objectives of this study were to provide information about the nesting biology of Megachile (Pseudocentron) gomphrenoides Vachal in an agro-ecosystem, including describing the structure of its nest, the materials employed for construction of brood cells, and the pollen resources used by females. In addition, we analyzed mortality factors, including parasites and cleptoparasites, and we provided data on floral hosts and associated organisms in trap-nests.

\section{MATERIALS AND METHODS}

\subsection{Study area}

The study was conducted in an agro-ecosystem in Hortensia (S 35'56'44.9”, W 61¹1'43.7"), Pdo. Carlos Casares, Buenos Aires, Argentina (Figure 1). The landscape is a mosaic of crop fields, sown pastures, and semi-natural grasslands used for livestock grazing. The main summer crops in this area are soybean (Glycine max), maize (Zea mays) and, to a lesser extent, sunflower (Helianthus annuus) and alfalfa (Medicago sativa). The climate is temperate sub-humid, with a mean annual precipitation of $1,022 \mathrm{~mm}$ for the last 25 years. Mean monthly temperatures vary from $7.2{ }^{\circ} \mathrm{C}$ in July to $23.8{ }^{\circ} \mathrm{C}$ in January (Tognetti et al., 2010). The regional flora includes many naturalized, non-native species, mostly from central Europe and the Mediterranean. Exotic species represent about $25 \%$ of the regional vascular flora (Tognetti et al., 2010).

\subsection{Nests collection}

Trap-nests were placed in the field during two agricultural years (November 2008 to March 2009 and November 2009 to March 2010) and monthly visited. During agricultural year 2008-2009, trap-nests were placed in the field margins of sunflower ( $n=5$ groups of bamboo canes) and maize ( $n=5$ groups), while in agricultural year 2009-2010 they were placed in the field margins of soybean ( $n=5$ groups) and in seminatural grassland that remains since agricultural practices have ceased ( $>20$ years; $n=5$ groups).

The trap-nests used in this study consisted of hollow bamboo canes, which were cut so that a nodal septum closed one end of the cane (Aguiar \& Garófalo, 2004). Previously, each cane was cut longitudinally and tape closed, and was measured in total length (from the entry to the node), and outer and inner diameters in the entry. In total, 170 and 140 bamboo canes were placed in November 2008 and November 2009, respectively, arranged in ten groups of 13-18 canes. At each monthly visit, the traps with nests were removed and taken to the laboratory. There, the cells were separated in plastic vials with cotton plugs and numbered from 1 to $n$ (starting by the innermost) and were kept in the laboratory at room conditions (ca. $15-25{ }^{\circ} \mathrm{C}$ ) until adult emergence. Later, adults were sexed and the emergence date registered. Cells that remained closed for a long time were opened to investigate whether an immature had died (egg or pre- or post-defecating larvae) or whether it was diapausing. The number and identity of parasites and cleptoparasites also were recorded.

\subsection{Nest and cell structure}

For each nest we recorded the number of cells formed, and some cells of different nests were measured ( $n=60$ of nine different nests). We counted the number of oblong cut leaves that were imbricately arranged to build walls and the number of circular cut leaves used for the top and base of each cell. To determine how many species of leaves were used by 


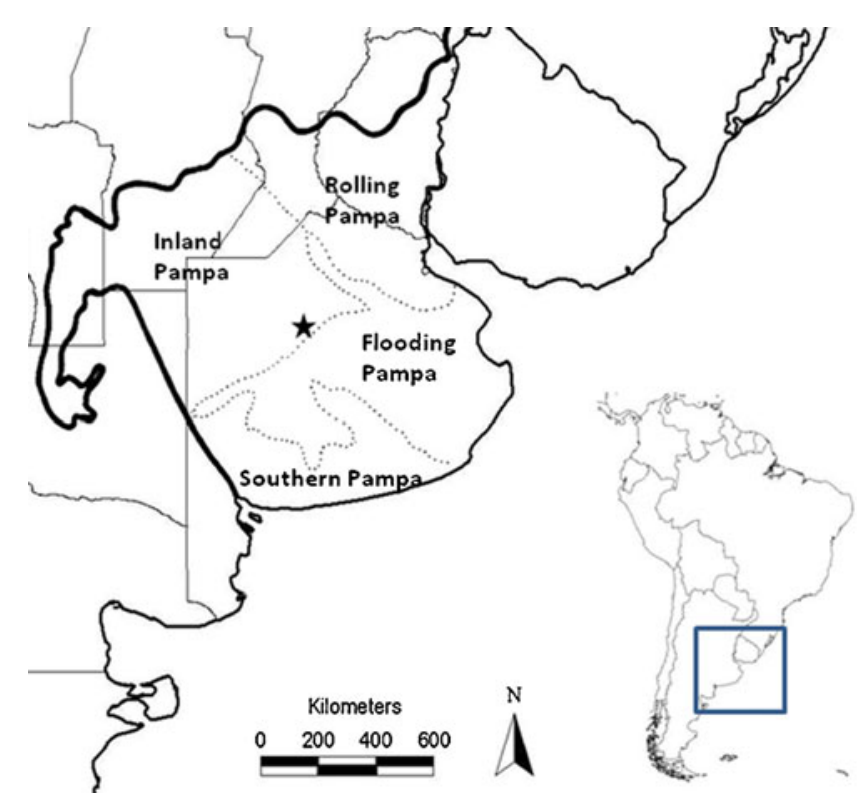

Figure 1. Study site (star) in the Pampean grasslands (area outlined by thick line). Subdivisions are delimited by dotted lines. Pampean limits taken from Soriano et al. (1991) and Hall et al. (1992).

female $M$. gomphrenoides, we performed diaphanization of the leaves of the cells $(n=28$ leaf pieces of 14 cells of six different nests) following conventional techniques (D'Ambrogio, 1986) and compared them with reference material collected from fields of potential plant species.

\subsection{Pollen analysis}

To explore the taxonomic identity of pollen consumed by larvae during development, we studied the pollen in the fecal pellets attached to the cocoon once adults had hatched. To do this, feces were placed in an Eppendorf tube and disaggregated according to conventional techniques (Rust et al., 2004) but without acetolyzation. In cells in which no adults hatched, we analyzed the pollen mass not consumed by the larvae. Later, under the microscope, we determined the taxonomic identity of the pollen grains ( $n=10$ cells of five different nests each year) at the lowest level possible in comparison with a pollen reference collection from plants in the study area. Of each sample, at least 500 pollen grains were counted and pollen taxonomic composition of each cell was analyzed as a percentage of the frequency of pollen $\left[\% \operatorname{taxon}_{i}=\left(\right.\right.$ number of pollen grains of $\operatorname{taxon}_{i} /$ total number of pollen grains) $\times 100$ ] (Villanueva-Gutiérrez \& Roubik, 2004).

\subsection{Floral hosts}

We obtained floral records of $M$. gomphrenoides during monthly visits to the study area (3-4 days for visits) by observing the foraging activity of adults of this species in the flowers of sunflower and weeds in field margin in 2008-2009 and in maize, their associated weeds and semi-natural grassland in 20092010. These observations were made between 9:00 h and 18:00 $\mathrm{h}$ on days when conditions were favorable for bee activity. All plant species having entomophilous flowers were recorded during each visit.

\section{RESULTS}

\subsection{Nests collection}

During 2 years of observation, 18 nests of $M$. gomphrenoides ( $n=9$ in 2008-2009 and $n=9$ in 2009-2010) were obtained from the trap-nests placed in the field margins (Table I). The mean 
Table I. Nesting of Megachile (Pseudocentron) gomphrenoides in trap-nests in an agro-ecosystem in Pampean region during 2 years of study.

\begin{tabular}{lll}
\hline & & Period \\
\cline { 2 - 3 } & $2008-2009$ & $2009-2010$ \\
\hline Trap-nests placed (groups) & $170(10)$ & $140(10)$ \\
Length (mean \pm SD) & $239 \pm 50.8$ & $254.9 \pm 39.7$ \\
Range & $130-353$ & $130-373$ \\
Trap-nests occupied (groups) & $9(3)$ & $9(5)$ \\
Length (mean \pm SD) & $267.1 \pm 42.4$ & $242.7 \pm 35.0$ \\
Range & $216-330$ & $203-323$ \\
Number of cells per nest & & \\
Mean \pm SD & $7.3 \pm 4.3$ & $7.8 \pm 3.4$ \\
Range & $2-16$ & $2-12$ \\
Total number of cells & 66 & 70 \\
Total number of emerged adults & 35 & 36 \\
Female/male ratio & $1.5 / 1$ & $2.2 / 1$ \\
Mortality rate & $47 \%$ & $48 \%$ \\
Mortality factors (cells, nests) & & $(25,8)$ \\
Larvae desiccated/molded & $(16,7)$ & $(5,3)$ \\
Post-defecating larvae or prepupae dead & $(5,4)$ & - \\
Melittobia attacks & $(7,3)$ & - \\
Horismenus attacks & $(3,2)$ & $(2,1)$ \\
Coelioxys attacks & - & $(2,2)$ \\
Tetraonyx attacks & - & \\
\hline Tap-nsts & & \\
\hline
\end{tabular}

Trap-nests placed, and occupied. Length (mean $\pm \mathrm{SD}$ ), number of cells (mean $\pm \mathrm{SD}$ ) per nest, number of total cells for year, number of adults emerged, female/male ratio, and mortality rates and factors

length of the trap-nests used by females of $M$. gomphrenoides was $254.9 \pm 39.7 \mathrm{~mm}$ (range, 203-330) with apertures of $8.22 \pm 1.39 \mathrm{~mm}$ (range, 6-11) in inner diameter and $13.00 \pm$ $1.74 \mathrm{~mm}$ (range, 9-17) in outer diameter. The nests contained from $7.55 \pm 3.77$ cells (range, $2-$ $16, n=136$ ).

A total of 35 and 36 adults of $M$. gomphrenoides emerged from the trap-nests in period 2008-2009 and 2009-2010, respectively (Table I). In the first study period, all nests were on the margins of sunflower plots, and in the second period on the margins of seminatural grassland. In both years, adults emergence showed a similar bimodal pattern, with a first peak in April-May, ca. 2 months (to 4 months) after egg-laying and a second peak in September-November, 7 to 11 months after egg-laying (Figure 2). Moreover, in both years, the sex ratio was female-biased, with a female/ male ratio of $1.5 / 1$ and $2.2 / 1$, respectively. Males hatched earlier, and occupied the outermost cells of each trap-nest. In each nest, male emergence precedes female emergence by $2-$ 10 days, but in some cases to 5 months. However, in two nests some females hatched before some males.

Throughout the study, the mortality of larvae, post-defecating larvae or prepupae due to desiccation or mold was high (30\%; Table I). Other mortality factors were insect natural enemies, although in low proportion. During 2008-2009, seven cells of three different nests were attacked by Melittobia hawaiiensis Perkins 


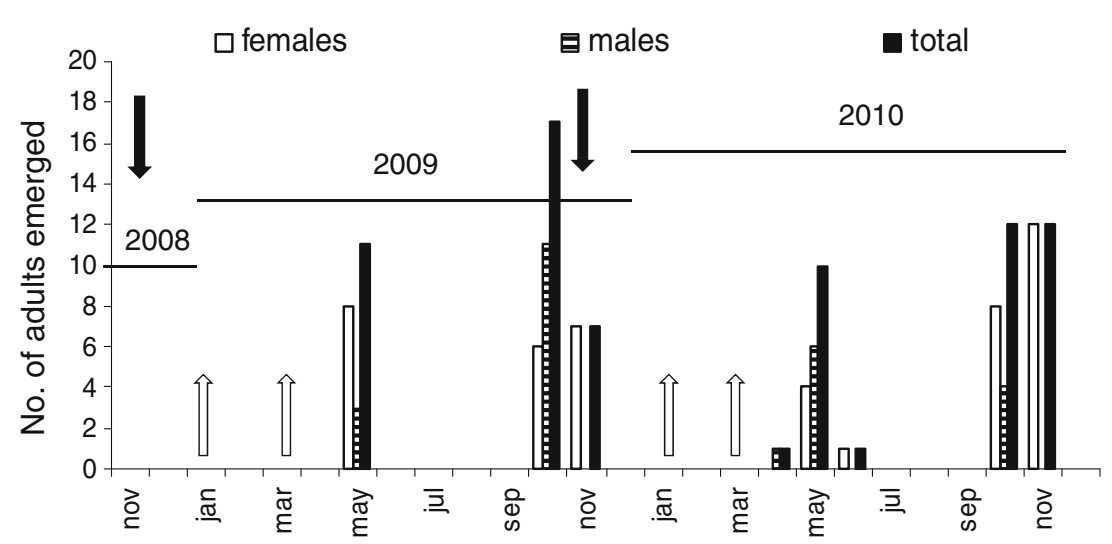

Figure 2. Emergence patterns of Megachile (Pseudocentron) gomphrenoides from trap-nests during 2 years of study in an agro-ecosystem in the Pampean region. Black top-down arrow date of placement of trap-nests. White bottom-up arrow date of retirement of traps with nests.

(Hymenoptera: Eulophidae: Tetrastichinae), and three cells in two nests by Horismenus sp. (Hymenoptera: Eulophidae: Entedoninae). In addition, in 2009-2010 two cells in one nest were attacked by Coelioxys (Glyptocoelioxys) remissa Holmberg (Hymenoptera: Megachilidae) and two cells in two other nests were attacked by the blister beetle Tetraonyx maudhuyi Pic (Coleoptera: Meloidae).

\subsection{Nest and cell structure}

The cells were arranged in linear series (Figure 3a), and each filled trap consisted of only one nest. The construction of most cells was initiated at the nodal septum, but in three nests the first cell was separated from the nodal septum by an empty space of 8-25 mm. All nests were closed with circular leaf pieces (4-16) (Figure 3b), with a vestibular space $(61-120 \mathrm{~mm})$ between the nest entry and the outermost cell.

Cells of M. gomphrenoides ( $n=34$, of four different nests) measured $14.34 \pm 1.28 \mathrm{~mm}$ (range, 11-17) in length. The cells consisted of $11 \pm 2.3$ (range, 5-18) imbricate oblong pieces of leaves for walls, $2.9 \pm 1.4$ and (range, 2-8) and $2.6 \pm 1.0$ (range, 1-7) circular leaf pieces were used for the construction of the cell closure and base, respectively (Figure 3c, $n=60$ of nine different nests). The basal area of each cell (except for the first cell) was embedded in the concave cap of the preceding one. When adults emerged, they chewed through the leaves capping each cell (Figure 3c)

We did not observe females actually cutting pieces of leaves, but the females of M. gomphrenoides used the leaves of at least three plant species: Robinia pseudoacacia, Chenopodium sp., and Trifolium sp., all of which were common plant species at our study site and were close to the position of the trap-nests.

\subsection{Pollen provisions}

Pollen provisions were yellow, moistened with nectar, and occupied half of the cell volume. The eggs were placed on the pollen masses (Figure 3d). Fecal pellets were yellow or yellow-orange in color, cylindrical $(2-3 \times 1 \mathrm{~mm})$ and deposited between the cocoon and the inner leaves within a cell (Figure 3e). The cocoon filled the inner dimensions of the cell, and was composed of one thin layer of silk threads embedded in a thicker dark brown matrix. Fecal material adhered to the external surface of the cocoon (Figure 3c) and was also found between the layers of silk, indicating that cocoon spinning and defecation overlap in time. 

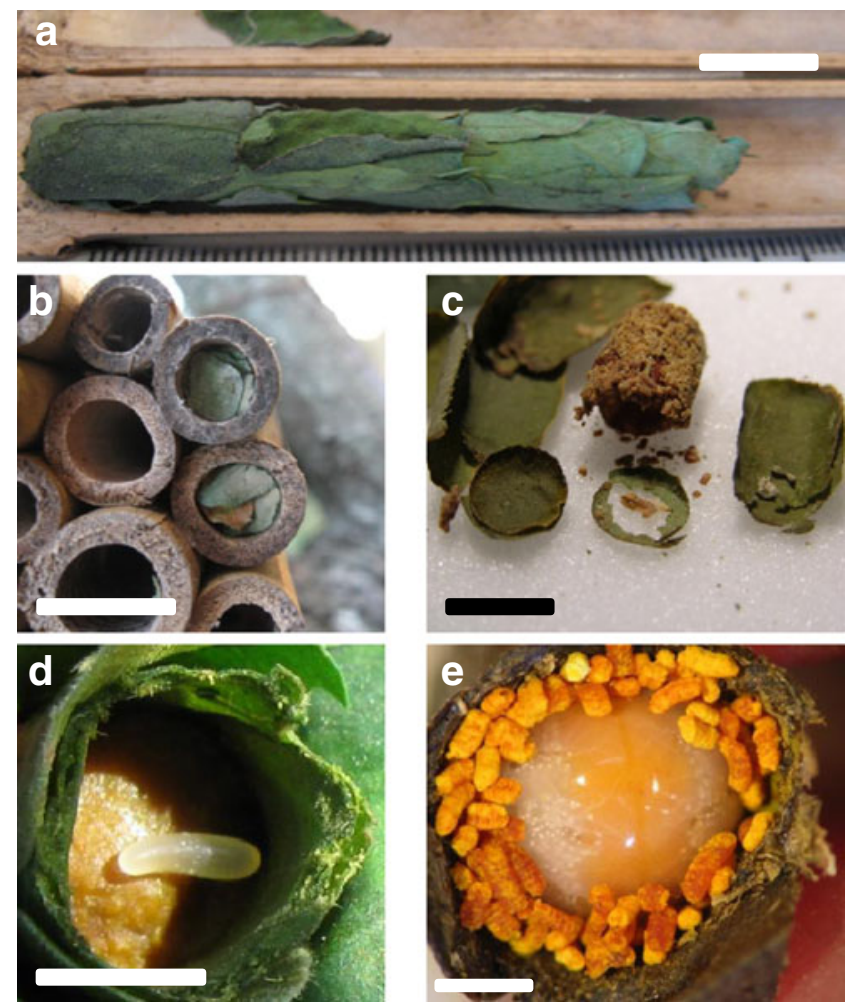

Figure 3. Nests of M. (Pseudocentron) gomphrenoides in trap-nests in an agro-ecosystem in the Pampean region. a Incomplete nest opened by the authors with three cells. b Complete nest closed with circular leaf pieces. $\mathbf{c}$ Cell after adult hatched. Note cocoon with fecal material adhering to the external surface, oblong and circular pieces of leaves, and hole gnawed by emerging adult. $\mathbf{d}$ Photographs of live egg on provisions. e Post-defecating larva in cell with fecal pellets (circular pieces of leaves were removed). Scale lines: a, b $1 \mathrm{~cm}, \mathbf{c}-\mathbf{d} 0.5 \mathrm{~cm}$, and e $0.3 \mathrm{~cm}$.

In the cells analyzed ( $n=10$ of four different nests), we found eight pollen types. Pollen typeBaccharis $(62.1 \pm 19.3 \%)$ and type-Carduus $(26 \pm 23.1 \%)$ were present in all cells, and in five cells of three nests pollen loads of sunflower (H. annuus) were found (19.7 \pm $13.3 \%$ ). Other pollen types found in minor proportions in some cells were type-Lactuceae, type-Inuleae, type-Apiaceae, type-Polygonum, and type-Chenopodium.

\subsection{Floral hosts}

Adults of M. gomphrenoides were collected in flowers of Baccharis pingraea, Carduus acanthoides, Cirsium vulgare, H. annuus (Astera- ceae), Ammi visnaga, Hydrocotyle bonariensis (Apiaceae), Hirschfeldia incana, Raphanus sativus (Brassicaceae), Adesmia bicolor (Fabaceae), and Portulaca oleracea (Portulaceae).

\section{DISCUSSION}

The nest architecture of $M$. gomphrenoides and the use of traps to build their nests agree with the reports on other species of Pseudocentron (Claude-Joseph, 1926; Tesón et al., 1976; Garófalo et al. 2004; Aguiar et al. 2005; Loyola and Martins, 2006). Female bees used leaves of different plant species, but did not use other plant material or mud for nest construction. The use of 
leaves of different plant species is widespread among Megachile spp. For example, M. (P.) poeyi Guérin in Cuba, which cut leaves of five plant species (Genaro, 1996) and M. (P.) gomphrenae Holmberg, in Buenos Aires (Argentina) used at least three species (Tesón et al., 1976).

While the number of nests obtained was relatively low $(n=18)$, we suggest that $M$. gomphrenoides could be a gregariously nesting leafcutting bee, as during the study the nests of this species were constructed in a few groups. However, females of solitary bees tend to build their nests close to each other, and because we did not mark the females during the nesting period, we do not know if the nests of the same block belong to more than one female. The emergence patterns observed in 2 years of study suggests that $M$. gomphrenoides has a facultative bivoltinism life cycle (Pitts-Singer and Cane 2011) because the emergence pattern of each age cohort is bimodal. The first generation of individuals originated before the winter (unfavorable season for bees in the study area), while the second generation originated during the spring, having spent the winter as post-defecating larvae or prepupae. Because the laboratory room conditions were cooler than those the trap-nests might have experienced in the field (less direct sunlight), the first generation may have taken longer to develop than would have occurred under natural conditions. In our study site, the activity pattern of adults of $M$. gomphrenoides ends in late-April when temperature decreases and the availability of flowering plants decreases. A similar bivoltine pattern has been described for Megachile (Chrysosarus) pseudanthidioides Moure (Zillikens and Steiner, 2004).

Females of $M$. gomphrenoides seem to be oligolectic on flowers of Asteraceae, collecting pollen mainly from the weeds $B$. pingraea, $C$. acanthoides, and $C$. vulgare in our study site. Also, nests built during the flowering of sunflower contained pollen of this crop in the analyzed provisions/feces. Females of $M$. gomphrenoides have been cited as common floral visitors of this crop in this area of study (Torretta et al. 2010). The presence of other pollen types in small proportions in the analyzed samples (provisions and feces) is likely an indication that females were foraging on these plant species for nectar (common weeds in our study site: Apiaceae, $A$. visnaga, $H$. bonariensis; others Asteraceae, tribe Lactuceae, Hypochaeris sp.; tribe Inuleae, Pluchea sp.) or looking for leaves to build the cells (e.g. Chenopodium sp., Chenopodiaceae).

The mortality rate observed in the nests of $M$. gomphrenoides was similar in both study periods (47 and $48 \%$, respectively). Approximately, $30 \%(28.57-31.82 \%)$ of all offspring failed to complete development to the adult stage. The principal mortality causes were unknown diseases causing the death of larvae and prepupae. Additionally, up to $15 \%$ (5.71$15.15 \%$ ) of all offspring were killed by several natural that attacked the nests, including parasitic eulophid wasps, a cleptoparasite megachilid and a bristle beetle. Brood parasitism of solitary bees by species of the cosmopolitan genus Melittobia is well documented (Matthews et al., 2009), while the predominantly Neotropical genus Horismenus are principally parasitoids or hyperparasitoids of larvae of Coleoptera, Diptera, and Lepidoptera (Hansson et al., 2004). However, our results are consistent with De Santis (1973), who reported that $M$. hawaiiensis and $H$. albipes develop as parasites of several species of Megachile in Buenos Aires Province.

On the other hand, it is known that most species of Coelioxys are cleptoparasites of Megachile, although some species attack Anthophora, Eucera, Tetraloniella, Centris, Xylocopa, or Euglossa (Michener 2007). Two specimens of $C$. remissa (a female and a male) were reared from the same nest, and their development was more rapid than that of their host (only 1 month). This species is a rare bee in our study area, but has been found in the nests of other species of Megachile (Torretta et al., unpublished data). The host/cleptoparasite association of M. gomphrenoides and $C$. remissa constitutes the first records for both species.

Two cells of $M$. gomphrenoides from two different nests were attacked by the blister beetle T. maudhuyi. While the records of meloid hosts include Apidae, Megachilidae, Halictidae, 
Andrenidae, Stenotritidae, Colletidae, and Melittidae (Roubik 1992; Pinto and Bologna 1999), the phoretic larvae of Tetraonyx, have, until now, been known to develop only in the nests of "anthophorid" (actually Apidae, sensu Michener 2007) bees (Pinto and Bologna 1999). Raw (2007) did not cite any species of Tetraonyx as a natural enemy of Megachile in his catalog of Neotropical leafcutting bees. This generic level host-parasite interaction was previously unknown. The larval floral host records of Nearctic bee-associated blister beetles are, principally, with the Asteraceae, although the two cited species of Tetraonyx were found on other plant families (Erickson et al., 1976). In Argentina, there is little biological data for $T$. maudhuyi. Selander and Martinez (1984) reported this beetle in flowers of a wild Liliaceae. In our study area, this blister beetle was seen in low abundance feeding on $C$. acanthoides, Cichorium intybus (Asteraceae), Verbena bonariensis, Verbena intermedia (Verbenaceae), and Dipsacus sativus (Dipsacaceae); however, we were unable to observe whether the females of T. maudhuyi use these inflorescences as oviposition sites.

M. gomphrenoides possesses some characteristics that make it a potential species for pollination of commercial sunflowers in the Pampean region. Some of them are (1) its size $(12-14 \mathrm{~mm}),(2)$ its use of trap nests, and (3) its oligolecty to flowers of Asteraceae, and use of sunflower as a pollen host. On the other hand, the synchrony of $M$. gomphrenoides' flight periods and sunflower bloom is low. In our study area, sunflower flowering is concentrated over a short period that may last 10-15 days for an individual head (Torretta et al. 2009), and 20-25 days at the field scale, during late December and early January, while adults of $M$. gomphrenoides are active during OctoberNovember and April. Basic knowledge about the developmental physiology of bee pollinators is essential for developing appropriate rearing methods (Bosch et al., 2008); therefore, additional works are required to determine other topics for the possible management of this leafcutting bee.

\section{ACKNOWLEDGMENTS}

To J. J. Martinez for the determination of Melittobia and Horismenus, H.J. Marrero and V. Fernández Corujo for unpublished data of interaction Tetraonyx and floral host. The manuscript benefited from critical reading by John L. Neff and two anonymous reviewers. Field work was supported by ANPCyT (PICT 08-12504 and 0851), Argentina. JPT is affiliated with CONICET.

Biologie de la nidification de l'abeille découpeuse de feuilles Megachile (Pseudocentron) gomphrenoides (Hymenoptera: Megachilidae) dans un agroécosystème.

\section{Abeilles solitaires / nid piège / pollinisation / Argentine}

Nestbiologie der Blattschneiderbiene Megachile (Pseudocentron) gomphrenoides (Hymenoptera: Megachilidae)in einem Agrar-Ökosystem.

Solitärbiene / Fallennest / Bestäubung / Argentinien

\section{REFERENCES}

Aguiar, C.M.L., Garófalo, C.A. (2004) Nesting biology of Centris (Hemisiella) tarsata Smith (Hymenoptera, Apidae, Centridini). Rev. Bras. Zool. 21, 477-486

Aguiar, C.M.L., Garófalo, C.A., Almeida, G.F. (2005) Trap-nesting bees (Hymenoptera, Apoidea) in areas of dry semideciduous forest and caatinga, Bahia. Brazil. Rev. Bras. Zool. 22, 1030-1038

Ascher J., Pickering, J. (2011) Bee species guide (Hymenoptera: Apoidea: Anthophila). http://www.discoverli fe.org $/ \mathrm{mp} / 20 \mathrm{q}$ ?guide=Apoidea_species. [accessed 23 Aug 2011].

Bosch, J., Sgolastra, F., Kemp, W.P. (2008) Life cycle ecophysiology of Osmia mason bees used as crop pollinators. In: James, R.R., Pitts-Singer, T.L. (eds.) Bee pollination in agricultural ecosystems, pp. 83104. Oxford University Press, New York

Buschini, M.L.T. (2006) Species diversity and community structure in trap-nesting bees in Southern Brazil. Apidologie 37, 58-66

Claude-Joseph, F. (1926) Recherches biologiques sur les Hyménoptères du Chili (Mellifères). Ann. Sci. Nat. Zool Paris 9, 113-268

D’Ambrogio, A.C. (1986) Manual de técnicas en histología vegetal. Hemisferio Sur, Buenos Aires 
De Santis, L. (1973) Himenópteros parásitos de "megaquilas" en la República Argentina. Ciencia y Abejas 6, 15-19

Donald, P.F., Evans, A.D. (2006) Habitat connectivity and matrix restoration: the wider implications of agrienvironment schemes. J. Appl. Ecol. 43, 209-218

Durante, S.P., Torretta, J.P. (2010) First description of male of Megachile (Pseudocentron) gomphrenoides Vachal and redescription of female (Hymenoptera, Megachilidae). T. Am. Entomol. Soc. 136, 235-240

Durante, S.P., Cabrera, N.C., Gómez de la Vega, L.E. (2008) Megachilidae. In: Claps, L.E., Debandi, G., Roig-Juñent, S. (eds.) Biodiversidad de artrópodos argentinos, vol. 2, pp. 421-433. Sociedad Entomológica Argentina ediciones, Mendoza

Erickson, E.H., Enns, W.R., Werner, F.G. (1976) Bionomics of the bee-associated Meloidae (Coleoptera); bee and plant hosts of some Nearctic meloid beetles - a synopsis. Ann. Entomol. Soc. Am. 69, 959-970

Freitas, B.M., Imperatriz-Fonseca, V.L., Medina, L.M., de MP, Kleinert A., Galetto, L., Nates-Parra, G., QuezadaEuán, J.J.G. (2009) Diversity, threats and conservation of native bees in the Neotropics. Apidologie 40, 332-346

Garófalo, C.A., Martins, C.F., Alves-dos-Santos, I. (2004) The brazilian solitary bee species caught in trap nests. In: Freitas, B.M., Pereira, J.O.P. (eds.) Solitary bees. Conservation, rearing and management for pollination, pp. 77-84. Imprensa Universitária, Fortaleza

Genaro, J.A. (1996) Plantas usadas por abejas del genero Megachile para construir las celdillas de sus nidos (Hymenoptera: Megachilidae). Caribb. J. Sci. 32, 365-368

Hall, A.J., Rebella, C.M., Ghersa, C.M., et al. (1992) Field-crop systems of the Pampas. In: Pearson, C.J. (ed.) Field Crop Ecosystems [Ecosystems of the World, 18], pp. 413-449. Elsevier, Amsterdam

Hansson, C., Aebi, A., Benrey, B. (2004) Horismenus species (Hymenoptera: Eulophidae) in a bruchid beetle parasitoid guild, including the description of a new species. Zootaxa 548, 1-16

Kremen, C., Williams, N.M., Thorp, R.W. (2002) Crop pollination from native bees at risk from agricultural intensification. Proc. Natl. Acad. Sci. USA 99, $16812-16816$

Krombein, K.V. (1967) Trap-nesting wasps and bees: life history, nests, and associated. Smithsonian Press, Washington

Loyola, R.D., Martins, R.P. (2006) Trap-nest occupation by solitary wasps and bees (Hymenoptera: Aculeata) in a forest urban remanent. Neotrop. Entomol. 35, 41-48

Matthews, R.W., González, J.M., Matthews, J.R., Deyrup, L.D. (2009) Biology of the parasitoid Melittobia (Hymenoptera: Eulophidae). Annu. Rev. Entomol. 54, 251-266

Medan, D., Torretta, J.P., Hodara, K., de la Fuente, E.B., Montaldo, N. (2011) Effects of agriculture expansion and intensification on the vertebrate and invertebrate diversity in the Pampas of Argentina. Biodivers. Conserv. 20, 3077-3100
Michener, C.D. (2007) The bees of the World, 2nd edn. Johns Hopkins University Press, Baltimore

Moure, J.S., Melo, G.A.R., DalMolin, A. (2007) Megachilini. In: Moure, J.S., Urban, D., Melo, G.A.R. (eds.) Catalogue of bees (Hymenoptera, Apoidea) in the Neotropical Region, pp. 917-1001. Sociedade Brasileira de Entomologia, Curitiba

Pinto, J.D., Bologna, M.A. (1999) The New World genera of Meloidae (Coleoptera): a key and synopsis. J. Nat. Hist. 33, 569-620

Pitts-Singer, T.L., Cane, J.H. (2011) The alfalfa leafcutting bee, Megachile rotundata: the world's most intensively managed solitary bee. Annu. Rev. Entomol. 56, 221-237

Raw, A. (2004) Ambivalence over Megachile. In: Freitas, B.M., Pereira, J.O.P. (eds.) Solitary bees. Conservation, rearing and management for pollination, pp. 175-184. Imprensa Universitária, Fortaleza

Raw, A. (2007) An annotated catalogue of the leafcutter and mason bees (genus Megachile) of the Neotropics. Zootaxa 1601, 1-127

Roig, A.A. (2008) Apiformes. In: Claps, L.E., Debandi, G., Roig-Juñent, S. (eds.) Biodiversidad de artrópodos argentinos, vol. 2, pp. 373-390. Sociedad Entomológica Argentina ediciones, Mendoza

Roubik, D.W. (1992) Ecology and natural history of tropical bees. Cambridge University Press, Cambridge

Rust, R.W., Cambon, G., Torre Gross, J.-P., Vaissière, B.E. (2004) Nesting biology and foraging ecology of the wood-boring bee Lithurgus chrysurus (Hymenoptera: Megachilidae). J. Kansas Entomol. Soc. 77, 269-279

Selander, R.B., Martinez, A. (1984) A synopsis of the genus Tetraonyx in Argentina (Coleoptera: Meloidae). Proc. Entomol. Soc. Wash. 86, 913-929

Silveira, F.A. (2004) Monitoring pollinating wild bees. In: Freitas, B.M., Pereira, J.O.P. (eds.) Solitary bees: conservation, rearing and management for pollination, pp. 73-76. Imprensa Universitária, Fortaleza

Soriano, A., León, R.J.C., Sala, O.E., et al. (1991) Río de la Plata grasslands. In: Coupland, R.T. (ed.) Natural grasslands. Introduction and Western Hemisphere. [Ecosystems of the World 8A], pp. 367-407. Elsevier, Amsterdam

Tesón, A., Dagoberto, E., Lizarralde, M., Loiácono, M. (1976) Himenópteros polinizadores de la zona de Bellocq (Buenos Aires-República Argentina). Ciencias y Abejas 2, 33-40

Tognetti, P.M., Chaneton, E.J., Omacini, M., Trebino, H.J., León, R.J.C. (2010) Exotic vs. native plant dominance over 20years of old-field succession on set-aside farmland in Argentina. Biol. Conser. 143, 2494-2503

Torretta, J.P., Durante, S.P. (2011) Nesting ecology of Megachile (Sayapis) mendozana Cockerell and its synonymy with Megachile (Sayapis) santiaguensis Durante (Hymenoptera: Megachilidae). Zootaxa 3008, 63-68 
Torretta, J.P., Navarro, F., Medan, D. (2009) Visitantes florales nocturnos del girasol (Helianthus annuus, Asterales: Asteraceae) en la Argentina. Rev. Soc. Entomol. Arg. 68, 339-350

Torretta, J.P., Medan, D., Roig, A.A., Montaldo, N. (2010) Visitantes florales diurnos del girasol (Helianthus annuus, Asterales: Asteraceae) en Argentina. Rev. Soc. Entomol. Arg. 69, 17-32

Villanueva-Gutiérrez, R., Roubik, D.W. (2004) Pollen sources of long-tongued solitary bees (Megachili- dae) in the Biosphere Reserve of Quitana Rôo, México. In: Freitas, B.M., Pereira, J.O.P. (eds.) Solitary bees. Conservation, rearing and management for pollination, pp. 185-190. Imprensa Universitária, Fortaleza

Zillikens, A., Steiner, J. (2004) Nest architecture, life cycle and cleptoparasite of the Neotropical leafcutting bee Megachile (Chrysosarus) pseudanthidioides Moure (Hymenoptera, Megachilidae). J. Kansas Entomol. Soc. 77, 193-202 